\title{
Pengenalan dan Pelatihan Dasa Teknik Biomolekuler bagi Mahasiswa S2 Biologi Universitas Cenderawasih
}

\author{
Daniel Lantang ${ }^{1}$, Arsyam Mawardi*2 \\ ${ }^{1,2}$ Program Studi Biologi, Universitas Cenderawasih \\ JLn. Kampwolker Uncem Waena, Jayapura, Papua 99583, Telp. +6285239558242 \\ e-mail korespondensi: mawardiarsyam@gmail.com
}

\begin{abstract}
The introduction of tools, reagents, and biomolecular techniques is the first step in molecular research, because knowing the tools, nature and character of the reagents, we know the functions of the tools and chemical reagents and their operation. Although biomolecular development has been rapid, S2biology students at FMIPA Cenderawasih University do not know about biomolecular tools and reagents. According to this problem, it is deemed necessary to hold training so they have the skills use the tools, understand the nature and function of reagents will facilitate students in research. The method of this acctivity is training in the laboratory. Stages of activities include: the preparation, the implementation, and the final stage (reporting). The results of the activity are during the practice, some students are specifically accompanied because operating biomolecular devices must be careful, pipetting needs precision and concentration. The participants were enthusiastic in whole series of events seen during the discussion session. The activity lasted until completion and no significant obstacles and difficulties. Even this activity grow up the knowledge and skills of students and increase understanding prospects of biomolecular projects. All support the educational process in the biology study program both in terms of learning and research of students.
\end{abstract}

Keywords :Biomolecular, Skill, Laboratory, Training

\begin{abstract}
Abstrak
Pengenalan alat, reagen, dan teknik biomolekuler merupakan langkah awal dalam melakukan penelitian molekuler, karena dengan mengenal alat, sifat dan karakter reagen, kita dapat mengetahui fungsi alat dan reagen kimia serta pengoperasiannya. Meskipun perkembangan biomolekuler telah pesat, namun mahasiswa S2 biologi FMIPA universitas Cenderawasih belum banyak mengetahui apa saja alat dan reagen biomolekuler, serta memaksimalkan penggunaannya. Beranjak dari hal tersebut, dipandang perlu untuk mengadakan pelatihan agar mereka memiliki skill dalam penggunaan alat, memahami sifat dan fungsi reagen yang akan memudahkan mahasiswa dalam melaksananakan riset molekuler. Metode pelaksanaan pelatihan ini adalah metode training di laboratorium Tahapan kegiatan meliputi: tahap persiapan, tahap pelaksanaan
\end{abstract}


Daniel Lantang, Arsyam Mawardi

kegiatan dan tahap akhir (pelaporan). Adapun hasil dari kegiatan yaitu pada saat praktek pengoperasian alat serta mencampur reagen, beberapa mahasiswa didampingi secara khusus oleh panitia karena proses pengoperasian alat biomolekuler perlu kehati-hatian, pemipetan yang menuntut ketepatan dan konsentrasi. Peserta antusias mengikuti seluruh rangkaian acara yang terlihat saat sesi diskusi dan tanya jawab. Kegiatan berlangsung hingga selesai dan tidak ditemukan kendala dan kesulitan yang signifikan. Bahkan kegiatan ini terbukti menambah pengetahuan dan keterampilan mahasiswa serta dapat menambah pemahaman tentang potensi dan prospek proyek biomolekuler. Semua menunjang proses pendidikan di program studi biologi baik dalam hal pembelajaran maupun penelitian tugas akhir mahasiswa.

Kata kunci : Biomolekuler, Keterampilan, Laboratorium Pelatihan

\section{PENDAHULUAN}

Dewasa ini sains biologi bearada pada titik dimana perkembangan bioteknologi dan molekuler sangat pesat. Beragam komposisi material genetik di setiap amakhluk hidup telah mampu untuk dikarakterisasi. perkembangan sains bioteknologi dan molekulerseakan memberi harapan bagi mahasiswa pascasarjana biologi pada saat mempelajari materi yang terkait bahasan keanekaragaman hayati, genetika molekuler,hingga rekayasa genetika, terutama pada ranah molekuler. Disamping sangat menunjang proses pembelajaran biologi di kampus, sekaligus sebagai wahana peningkatan kapasitas terutama kompetensi akademik karena tuntutan jamanmenuntut mahasiswa pascarsarjana untuk mengikuti perkembangan terkini pada bidang biologi.

Pengenalan alat dan reagen serta teknik biomolekuler merupakan langkah pertama sebelum kita melakukan percobaan atau penelitian molekuler, karena dengan mengenal alat, sifat dan karakter reagen, kita dapat mengetahui fungsi masing-masing bagian dari alat dan reagen kimia tersebut serta cara pengoperasian atau penerapannya yang akan dipakai dalam percobaan atau penelitian yang dilakukan. Dengan mengetahui fungsi, cara penggunaan alat-alat serta prinsip kerja dasar biomolekuler, akan sangat berguna untuk memperlancar jalannya suatu percobaan atau penelitian beraras molekuler. Sehingga dengan berbekal pengetahuan pemahaman akan fungsi dan cara kerja dari alat yang digunakan kita dapat memperoleh hasil suatu percobaan atau penelitian yang maksimal (Bibiana, 2007).

Selain pengetahuan pemahaman akan alat, kita juga dituntut untuk terampil dalam alat-alat yang kita gunakan, misalnya dalam bidang Bioteknologi yang merupakan penerapan suatu prinsip-prinsip biologi, biokimia dan rekayasa dalam pengolahan bahan dan agensia jasad hidup dan komponen-komponennya untuk menghasilkan barang dan jasa. Di banyak tempat bioteknologi memiliki laboratorium dimana kegiatan rekayasa dan perakitan material genetik dilakukan. Dalam laboratorium tersebut terdapat berbagai macam alat dan reagen-reagen yang memiliki fungsi cara penggunaan yang beranekaragam (Choudhary, 2008). Pada dasarnya setiap alat dalam biomolekuler memiliki nama yang menunjukkan kegunaan alat, prinsip kerja atau proses yang berlangsung ketika alat digunakan. Beberapa kegunaan alat dapat dikenali berdasarkan namanya. Penamaan alat-alat yang berfungsi mengukur 
biasanya diakhiri dengan kata meter seperti thermometer, hygrometer dan spektrofotometer, dan lain-lain Alat-alat pengukur yang disertai dengan informasi tertulis, biasanya diberi tambahan grap seperti thermograph, barograph (Yulita, 2012).

Alat dan bahan yang digunakan dalam kegiatan di laboratorium memerlukan perlakuan khusus sesuai sifat dan karakteristik masing-masing. Perlakuan yang salah dalam membawa, menggunakan dan menyimpan alat dan bahan di laboratorium bioteknologi bagian molekuler dapat menyebabkan kerusakan alat dan bahan, terjadinya kecelakaan kerja serta dapat menimbulkan penyakit. Cara memperlakukan alat dan bahan di laboratorium secara tepat dapat menentukan keberhasilan dan kelancaran kegiatan. Adapun perlakuan terhadap alat-alat di laboratorium seperti membawa alat sesuai petunjuk penggunaan, menggunakan alat sesuai petunjuk penggunaan, menjaga kebersihan alat dan menyimpan alat (Triwibowo, 2005). Peralatan dan reagen-reagen molekuler yang berbahan kimia ini kemungkinan dapat menimbulkan resiko pada pemakainya atau menimbulkan kerusakan apabila salah prosedur dalam mengoperasikannya (Wetherel,2008). Lebih dari itu, pemahaman karakteristik dan sifat reagen, cara penggunaan alat, dan prinsip teknik biomolekuler sangat berperan penting dalam kemudahan mengerjakan proyek-proyek bioteknologi molekuler di bidang kesehatan, pertanian, lingkungan, hingga industri.

Meskipun perkembangan biologi molekuler telah ada dan berkembang, namun mahasiswa pascasarjana biologi di FMIPA universitas Cenderawasih belum banyak mengetahui apa saja alat dan reagen biomolekuler, bagaimana memanfaatkan dasar teknik biomolekuler secara maksimal. Beranjak dari hal tersebut, dipandang perlu untuk mengadakan kegiatan pelatihan seperti ini.Berdasarkan pemahaman serta uraian tersebut maka sangat penting untuk dilakukan pengenalan dan pelatihan dasar teknik biomolekuler di Laboratorium agar mahasiswa S2 Biologi memiliki skill saat penggunaan alat, memahami sifat dan fungsi reagen serta memudahkan mahasiswa S2 Biologi dalam melaksananakan riset di bidang molekuler.

\section{METODE}

Output kegiatan ini adalah mahasiswa S2 Biologi memiliki skill dasar untuk bekerja dan menggunakan alat dan reagen biomolekuler. Untuk mencapai tujuan tersebut, kegiatan ini perlu direncanakan dengan baik agar dapat mencapai tujuan tersebut. Metode pelaksanaan kegiatan ini adalah metode training yang dilakukan di dalam laboratorium Oleh karena itu diperlukan tahapan-tahapan kegiatan pengabdian sebagai sebagai berikut:Analisa situasi dan kebutuhan, tahap persiapan, tahap pelaksanaan kegiatan dan tahap akhir (pelaporan).

Kegiatan yang dilakukan pada tahapan Analisa situasi dan kebutuhan ialah menganalisa kebutuhan mahasiswa S2 Biologi FMIPA Universitas Cenderawasih Kota jayapura. Kegiatan yang dilakukan pada tahap persiapan ini adalah: (1) pembentukan panitia pelaksana kegiatan pelatihan; (2) pembuatan proposal dan menyelesaikan administrasi dengan pihak Lembaga Pengabdian kepada Masyarakat; (3) survey tempat pelaksanaan kegiatan pelatihan; (4) membuat brosur tentang kegiatan pelatihan; (5) penyebaran brosur ke pasca sarjana; (7) pembuatan modul 
Daniel Lantang, Arsyam Mawardi

Tahap pelaksanaan kegiatan yang meliputi: (1) registrasi peserta; (2) pembukaan. (3) penyampaian materi konsep dasar biologi molekuler (gen, DNA, asam amino dan protein), (4) pemberian pre test, (5)Pengenalan dan pelatihan pemanfaatan alat/ reagen di laboratorium (6) praktek dan pendampingan (6)evaluasi berupa post test. Untuk mengukur sejauh mana respon dam tingkat pemahaman peserta terhadap

Sedangkan pada tahap akhir, hasil kegiatan akan diseminarkan dan dilaporkan ke pihak LPPM selaku pengelola kegiatan Pengabdian kepada Masyarakat di Universitas Cenderawasih.

\section{HASIL DAN PEMBAHASAN}

Adapun hasil dari kegiatan pengenalan dan pelatihan dasar teknik biomolekuler bagi mahasiswa S2 Biologi FMIPA Universitas Cenderawasih dalam upaya memberikan pengetahuan dan keterampilan penggunaan alat, reagen dan dasar teknik biomolekuler, serta untuk edukasi tentang potensi dan prospek biomolekuler di era modern, antara lain:

1. Pada saat praktek pengoperasian beberapa alat serta mencampur reagen. beberapa mahasiswa perlu didampingi secara khusus oleh panitia penyelenggara karena proses pengoperasian alat biomolekuler perlu ketelatenan, hati-hati, selain itu pemipetan yang menuntut ketelitian dan ketepatan, serta membutuhkan konsentrasi.

2. Selama berlangsungnya kegiatan pelatihan, peserta terlihat begitu antusias mengikuti seluruh rangkaian acara pelatihan, hal tersebut terlihat saat sesi diskusi dan tanya jawab. Di sesi tanya jawab tersebut, panitia penyelenggara memberikan cinedaramata dan door prize bagi peserta yang terpilih dan berhasil menguraikan jawaban secara tepat dan cepat.

Kegiatan pelatihan ini dilaksanakan selama satu hari. Kegiatan pengabdian ini mencakup Realisasi program berupa penyampaian materi konsep dasar biologi molekuler (gen, DNA, asam amino dan protein), pemberian tes awal, hingga pendampingan praktek dasar dari teknik biomolekuler, post test. Kegiatan tahap awal berupa penyampaian materi presentasi, dilaksanakan pada pagi harinya, adapun materi presentasi yang diberikan meliputi masalah konsep dasar biologi molekuler (gen, DNA, asam amino dan protein), pengertian biomolekuler, teknik-teknik dasar biomolekuler, serta prospek proyek biomolekuler saat ini dan di masa mendatang. Kegiatan tahap kedua yaitu praktek atau demontrasi yang dilaksanakan pada siang hari nya. Kegiatan demontrasi ini memperagakan langkah-langkah pembuatan campuran beberapa reagen kimia, penggunaan dan pengoperasian alat-alat di laoratorium. Kegiatan tahap ketiga yaitu kegiatan praktik yang akan dilakukan langsung oleh peserta pelatihan yang dibagi ke dalam beberapa kelompok. Pada tahapan ini peserta diberikan kesempatan untuk melakukan isolasi DNA, membuat campuran dan mixing reagen untuk reaksi amplifikasi gen, serta menjalankan serta menekan tombol-tombol pada alat yang pengoperasiannya secara langsung.

Berdasarkan pengamatan pada saat pelatihan ini berlangsung hingga selesai tidak ditemukan kendala dan kesulitan yang signifikan, akan tetapi pelatihan seperti ini seyogyanya berlangsung secara simultan dan berkelanjutan, tujuannya tentu agar 
mahasiswa S2 Program studi Biologi dapat memperluas pengetahuan dan keterampilan penggunaan alat, reagen dan dasar teknik biomolekuler, serta dapat menambah khazanah keilmuan tentang potensi dan prospek Biomolekuler saat ini dan prospeknya di masa depan.

\section{Simpulan}

\section{PENUTUP}

Kegiatan pengenalan dan pelatihan dasar teknik biomolekuler memberi manfaat bagi mahasiswa s2 biologi fmipa universitas cenderawasih serta para dosen/ akademisi yang tertarik, terbukti mampu menambah pengetahuan dan keterampilan penggunaan alat, reagen dan dasar teknik biomolekuler serta dapat menambah pemahaman tentang potensi dan prospek proyek-proyek biomolekuler di era modern. Semua ini diperlukan guna menunjang proses pendidikan di program studi biologi baik dalam hal pembelajaran maupun dalam penelitian tugas akhir mahasiswa.

\section{Saran}

Diharapkan adanya pelatihan lanjutan yang lebih advance untuk meningkatkan kualitas pembelajaran dan penelitian di bidang biologi molekuler dan bioteknologi

\section{Ucapan Terima Kasih}

Penulis mengucapkan terima kasih kepada Lembaga Penelitian dan Pengabdian Kepada Masyarakat Universitas Cenderawasih melalui skema pembiayaan PNBP Universitas Cenderawasih yang telah memberi dukungan finansial terhadap penelitian ini.

\section{DAFTAR PUSTAKA}

Bibiana, W. Lay, 2007. Bioteknologi. Jakarta : Rajawali pers.

Choudhary, M.I, 2008. Keselamatan dan Keamanan Laboratorium Kimia. Jakarta: Yudhistira.

Yulita, 2012. Pengenalan Alat Laboratorium Bioteknologi. Fakultas Pertanian. Universitas Hasanuddin.

Triwibowo, Y. 2005 Biologi Molekuler. Penerbit Universitas Erlangga, Surabaya.

Wetherel, D.F, 2008. Propagasi Tanaman Secara In Vitro. New Jersey: Avery Publishing Group Inc. 